CERE Working Paper, 2019:1

\title{
Planning on a wider scale - Swedish forest owners' preferences for landscape policy attributes
}

Göran Bostedt, Astrid Zabel and Hans Ekvall

The Centre for Environmental and Resource Economics (CERE) is an inter-disciplinary and inter-university research centre at the Umeå Campus: Umeå University and the Swedish University of Agricultural Sciences. The main objectives with the Centre are to tie together research groups at the different departments and universities; provide seminars and workshops within the field of environmental \& resource economics and management; and constitute a platform for a creative and strong research environment within the field.

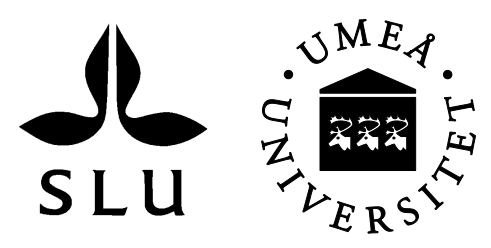




\title{
Planning on a wider scale - Swedish forest owners' preferences for landscape policy attributes
}

\author{
Göran Bostedt ${ }^{\mathrm{a}, \mathrm{c}}$, Astrid Zabel ${ }^{\mathrm{b}}$ \& Hans Ekvall ${ }^{\mathrm{c}}$
}

${ }^{a}$ CERE, Centre of Environmental and Resource Economics, Umeå School of Business and Economics, Umeå University, S-901 87 Umeå, Sweden.

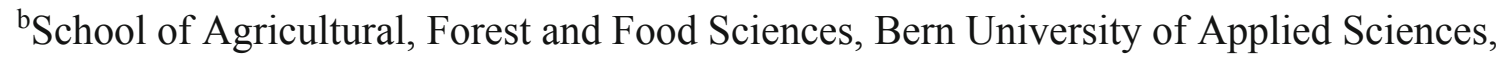
Länggasse 85, 3052 Zollikofen, Switzerland

'Department of Forest Economics, Swedish University of Agricultural Sciences,

SLU, S-901 83, Umeå, Sweden. 


\begin{abstract}
A tax-fund system has been proposed to advance Swedish forest conservation. We present a choice experiment with Swedish private forest owners on preferences for attributes of a taxfund system. Focusing on three aspects: (i) freedom to choose set-asides, (ii) equity issues, and (iii) frequency of nature inventories, we find two groups of forest owners. The first is opposed to interventions that could curtail liberty and oppose frequent nature inventories, while a smaller group would derive positive utility from joint decision-making. A tax-fund system would need to be designed in a participatory manner to reconcile forest owners, forest industry, and conservationists.
\end{abstract}

Keywords: Choice experiments; biodiversity; boreal forest; landscape planning; Sweden JEL codes: Q23, Q28, Q51, Q58 


\section{Introduction}

In the Swedish forestry sector, profitability considerations often lead to silvicultural management decisions that are in conflict with society's environmental conservation goals. The forest industry is an important sector of the national economy, providing employment for 9$12 \%$ of the country's industry work force (KSLA 2015). Internationally, Sweden is among the largest exporters of pulp and paper. To remain competitive, efficiency considerations have been key, leading to intensive forestry with a high degree of mechanization.

"Sustainable forests" is one out of 16 environmental quality objectives adopted by the Swedish parliament in 1999 that define the environmental dimensions of sustainable development and set out milestones and goals to be achieved by 2020 (Liljenström \& Kvarnbäck 2008). The goal "sustainable forests" and states that "The value of forests and forest land for biological production must be protected, at the same time as biological diversity and cultural heritage and recreational assets are safeguarded." This objective description clearly acknowledges the dissenting needs of managing forests for production and conservation.

A recent evaluation assesses that the environmental quality objective sustainable forests "has not been achieved and cannot be achieved with existing and approved instruments and measures" (Naturvårdsverket 2017). The evaluation highlights the need for measures to halt habitat loss and fragmentation while criticizing that current environmental initiatives are insufficient. Forest conservation policies in Sweden mostly are top-down approaches, such as land acquisitions through the government or impositions of restrictions on owners' access rights.

The application of legal conservation instruments restricts, more or less, land owners right to make use of forest land, e.g. to carry out felling. With some exceptions, the land owner is entitled to compensation if restrictions "considerably obstruct ongoing land use on the relevant part of the property". This rather complicated norm has in practice been operationalized to imply that about $5 \%$ of the value of the relevant forest area is what the land owner should be able to tolerate at the most.

In recent years voluntary nature conservation agreements have gained in importance, yet with mixed results (Appelstrand 2012, Widman 2015). There is clear need for policy reform to achieve the given environmental objectives in the context of an active and economically strong forest industry. 
Zabel et al. (2018) propose a tax-fund system as policy mechanism to advance conservation of ecologically valuable forests and to improve connectivity of set aside forests. A tax-fund system builds on the concept of common but differentiated responsibility in landscapes with a heterogeneous distribution of ecologically valuable forests across land owners.

In a tax-fund system, forest owners with a lot of ecologically valuable forests would be compensated through the fund for limitations of using their forest that go beyond the $5 \%$ rule. Forest owners with ecologically less valuable forests would be allowed to harvest more than in the present situation. They would however be required to pay a tax which would be used to aliment the fund. A number of design options are discussed in Zabel et al. (2018) from a theoretical perspective. However, investigating forest owners' opinions and preferences is crucial for the assessment of policy acceptance and political feasibility of a major policy reform (Dreyer \& Walker, 2013; Dreyer et al., 2015; Ščasný et al., 2017). In Sweden this is particularly relevant given the economic importance of the forestry sector.

In this paper we contribute to the debate by presenting empirical results on Swedish forest owners' preferences of different policy design options for a tax-fund system. We focus on three aspects: (i) freedom to choose the location of set-aside stands, (ii) vertical equity in terms of the repartition of conservation costs between forest owners and society as well as horizontal equity concerning the basis on which the tax will be imposed, and (iii) the frequency of nature inventories. These aspects build on three strands of literature that are discussed in section 2 below. The remainder of the paper is structured as follows: Section 3 presents the attribute levels and the set-up of the choice experiment, section 4 presents the results, section 5 discusses policy implications and section 6 concludes.

\section{Policy design options}

"Freedom with Responsibility" has been a key governance paradigm in the Swedish forestry sector for more than two decades (Lindahl et al. 2017). The first part, "freedom", implies that forest owners have wide ranging autonomy, including the possibility to choose the location of set aside sites on their estate. The resulting lack of coordination in choosing the location of set asides is likely to have contributed to the current fragmentation problem. Implementing a landscape approach would necessitate prescriptions on the location of set asides or, in the minimum, some form of coordination or guidance by authorities that could limit forest owners' freedom. The second term "responsibility", in this context, can be broken down into obedience 
of existing rules, care for the ecosystem and liability (Löfmarck et al. 2017). Rules on set asides exist in the Swedish Forestry Act, but in practice possibilities for prosecution of violations are limited (Forsberg 2012). Formalizing a type of sector responsibility for environmental conservation is an idea that has entered forest policy discussions already decades ago and led to a highly polarized debate (Bush 2010). In this study we seek to investigate how much forest owners value their current "freedom with responsibility" in choosing the location of set asides against limitations of this freedom in order to improve nature conservation within the larger landscape.

The debate revolving around the responsibility of the forest sector for biodiversity protection has been intimately tied to a debate on financial responsibility and equity, the latter of which has many different conceptions including vertical and horizontal equity (Cazorla \& Toman 2000, Bush 2010). Today, forest owners have a right to compensation when "ongoing land use is considerably obstructed in a relevant part of the property" (Environmental Code, chapter 31, section 4). Forest owners, in practice, receive compensation if restrictions surpass $5 \%$ of their declared annual income from the forest estate. In other words, any obstruction beyond the 5\% limit is currently compensated for by society at large. Increasing this limit (e.g. to 6\%) can be interpreted as an increase in vertical equity (and also a shift toward the polluter pays principle), whereas decreasing the limit (e.g. to $4 \%$ ) corresponds to a decrease in vertical equity (and a shift toward the beneficiary pays principle). An example of a forestry tax-fund system building on high vertical equity is the green tax in Croatia. This green tax is charged on the revenue of all legal and physical Croatian persons and the tax proceeds are used to support various forest related activities in state and private forests, inter alia infrastructure and ecosystem service provision as well as forest-related research (Pešut 2011). In the choice experiment we investigate forest owners' preferences concerning vertical equity by varying the limit for compensation in the choice sets.

Horizontal equity in our context means that forest owners with similar economic circumstances bear a similar economic burden for conservation. Much research has been conducted on different forestry taxes and their effects on rotation age. This literature is summarized e.g. in Englin \& Klan (1990), and Amacher et al. (2009). However little is known on forest owners' preferences for different bases used to compute individual shares of the burden. In our analysis we investigate whether forest owners would prefer a change in the basis used to calculate the limit for when land use is significantly hampered and compensation should be paid. The base presently used is the declared annual income from the forest estate. The alternatives we 
presented to forest owners in the choice experiment were the production capacity of the forest land and the size of the standing timber volume.

Finally, the frequency of nature inventories was included as an attribute in the choice experiment to investigate forest owners' preferences for, or perhaps opposition to, the collection of detailed information of nature values on their estate. At the time of the experiment design (2017), there was a major debate on nature inventories to identify key-biotopes in Sweden. In spring 2017 the Swedish Forest Agency announced that it will pause nature inventories in North-Western Sweden due to concern over deficient and possibly unequal inventory methods. The announcement of the inventory pause came by surprise and triggered a heated debate with conservationists arguing that the pause will incentivize rapid clear-cutting of ecologically valuable forests (Larsson 2017). Forest owner representatives by contrast welcomed the pause. While the Forest Agency does not completely ban timber harvesting in key-biotopes, in practice the identification of a key-biotope is equivalent to a harvesting ban for forest owners who are FSC or PEFC certified (Larsson 2017). This is due to the certification organizations' stipulations that timber from key-biotopes may not be harvested and certified timber purchasers may not buy wood sourced in key-biotopes. By September 2017 it became clear that the government will substantially increase the national budget to conduct the nature inventories and to compensate forest owners for production losses. The inventory pause ended in January 2018. The Swedish nature inventory debate has many parallels to the controversy on the northern spotted owl in the 1990ies in the USA. In the case of the spotted owl, a large debate on conservation versus employment emerged after the owl was set on an endangered species list resulting in timber harvesting restrictions to protect the owls' habitat (Kirschner 2010). For the choice experiment presented in this paper, the assumption is that more frequent nature inventories are a disutility to forest owners.

\section{Choice experiment}

The choice experiment (CE) method is by now well established for estimating the value of changes in the characteristics of environmental goods and qualities. This method can value hypothetical future scenarios and allow for estimating the marginal value of change in each characteristic that the $\mathrm{CE}$ includes. By using the $\mathrm{CE}$ method, this study aims at estimating the benefits derived from changing the attributes in the current forest policy in order to implement a forest landscape planning policy. By being able to measure the marginal value of changes in 
various attributes of a forest policy through choices between the current policy state to alternate policy states, it is possible to estimate the relative importance of changing these different attributes of forest policy. This provides policymakers with valuable information which can be used to help design a forest landscape planning policy that is acceptable to Swedish private forest owners.

\subsection{Policy attributes}

The forest policy attributes included in the CE are grouped around the three issues discussed in section two above: (i) Who decides on the location of forest set-aside areas, (ii) Which tax base should be used in a tax-fund system, and (iii) Should decisions be based on biannual nature inventories? In addition, there is a (iv) Cost attribute, defined as How large set-asides should the forest owner have to accept before compensation is paid. This fourth attribute represents a measure of the economic sacrifice of the forest owner, and hence becomes an indirect measure of the marginal utility of money. It should be noted that this cost attribute is described to the respondents in terms of percent of the present value of timber production, which makes comparison with the status quo, $5 \%$, easier.

The selection of the aforementioned attributes is motivated because they are expected to significantly affect the non-industrial private forest (NIPF) owners' utility. Furthermore, they are critical characteristics of a tax-fund system that will need to be decided on before implementation. When answering the choice sets, the respondents were asked to consider the next 10 years of forest management, since a longer time perspective was not deemed realistic to ask the respondents to consider.

The first attribute is about who has the right to decide on the location of set-asides: the forest owners or society (e.g. the Swedish Forest Agency, the Swedish Environmental Protection Agency and/or County Administrative Boards), and whether these set-asides can be distributed non-proportionally between forest owners in a landscape. The attribute had four alternative levels:

- Society decides, and the set-asides are distributed between forest owners in proportion to the area of the estate.

- Society decides, and the set-asides are distributed between forest owners in proportion to the biological value of the estate. 
- Society and the forest owner decide together, and the set-asides are distributed between forest owners in proportion to the biological value of the estate.

- The forest owner decides himself in accordance with current legislation (the status quo level).

The second attribute, Which tax base should be used in a tax-fund system, is about which base to use to calculate the limit for when land use is significantly hampered and compensation should be paid. The attribute had three alternative levels:

- In proportion to the production capacity of the forest land (i.e. site quality class).

- In proportion to the size of the standing timber volume.

- In proportion to declared annual income from the forest estate (the status quo level).

The third attribute, Should decisions be based on biannual nature inventories, is about how often the biological information underpinning the forest landscape policy is revised. The attribute was phrased as "nature conservation inventories are conducted biannually", with two levels: Yes and No, as today, where the current frequency, was defined as approximately once in 30 years. In reality this frequency varies significantly, but is roughly 30 years. In practice, an average NIPF owner in Sweden is unlikely to experience a nature inventory in his/her estate in their lifetime, which means that biannual nature inventories would be a relatively dramatic increase in frequency.

The final attribute, Cost, was described to the respondents in terms of percent of the present value of timber production. The attribute had four levels, $1 \%, 5 \%$ (the status quo level), $10 \%$ and $15 \%$. 
Table 1. Attributes and levels in the choice experiment

\begin{tabular}{|c|c|c|c|c|}
\hline Attribute $\rightarrow$ & $\begin{array}{l}\text { Freedom to decide } \\
\text { location of set- } \\
\text { asides }\end{array}$ & $\begin{array}{l}\text { Which tax base } \\
\text { should be used } \\
\text { in a tax-fund } \\
\text { system }\end{array}$ & $\begin{array}{l}\text { Should } \\
\text { decisions be } \\
\text { based on } \\
\text { biannual nature } \\
\text { inventories? }\end{array}$ & $\begin{array}{l}\text { Cost (in terms } \\
\text { of percent of } \\
\text { the present } \\
\text { value of timber } \\
\text { production) }\end{array}$ \\
\hline Status quo level & $\begin{array}{l}\text { The forest owner } \\
\text { decides himself in } \\
\text { accordance with } \\
\text { current legislation }\end{array}$ & $\begin{array}{l}\text { In proportion to } \\
\text { declared annual } \\
\text { income from the } \\
\text { forest estate }\end{array}$ & No, as today & $5 \%$ \\
\hline Alternative level 1 & $\begin{array}{l}\text { Society decides, and } \\
\text { the set-asides are } \\
\text { distributed between } \\
\text { forest owners in } \\
\text { proportion to the area } \\
\text { of the estate. }\end{array}$ & $\begin{array}{l}\text { In proportion to } \\
\text { the production } \\
\text { capacity of the } \\
\text { forest land (i.e. site } \\
\text { quality class). }\end{array}$ & Yes & $1 \%$ \\
\hline Alternative level 2 & $\begin{array}{l}\text { Society and the forest } \\
\text { owner decide } \\
\text { together, and the set- } \\
\text { asides are distributed } \\
\text { between forest owners } \\
\text { in proportion to the } \\
\text { biological value of the } \\
\text { estate }\end{array}$ & $\begin{array}{l}\text { In proportion to } \\
\text { the size of the } \\
\text { standing timber } \\
\text { volume. }\end{array}$ & & $10 \%$ \\
\hline Alternative level 3 & $\begin{array}{l}\text { Society and the forest } \\
\text { owner decide } \\
\text { together, and the set- } \\
\text { asides are distributed } \\
\text { between forest owners } \\
\text { in proportion to the } \\
\text { biological value of the } \\
\text { estate }\end{array}$ & & & $15 \%$ \\
\hline
\end{tabular}

\subsection{Experimental design}

An orthogonal fractional factorial design was used to construct the choice sets. Prior expectations regarding the utility effect of each attribute and dominant alternatives were used to create the design using the Ngene software. While efficient designs have the advantage of requiring smaller sample sizes and enabling smaller designs in terms of the number of choice sets, they also require prior information of the expected magnitude of the coefficients. For this reason, and given the unavailability of such prior information an orthogonal fractional factorial design was chosen. Following Street \& Burgess (2007), unrealistic combinations of choice alternatives were excluded from the full design. 
The final experimental design consisted of 24 choice sets, divided into 3 blocks. This meant that 8 choice sets were then presented to each respondent. Each choice set was comprised of three alternatives, including a Status quo alternative. The alternatives were presented to the individuals, who were asked to choose their most preferred alternative.

\subsection{Econometric approach}

The multinomial logit (MNL) model (McFadden, 1974) is the most widely used approach for choice modelling and it is often the starting point for analysis. This was also the case here where a MNL model was used for the initial analysis of the data. But the MNL model is associated with some limitations such as an inability to capture unobserved heterogeneity among individuals, account for the panel nature of repeated choices, and it is associated with the assumption of independence of irrelevant alternatives (IIA) (Train, 2003). Latent class modelling is one of many approaches for introducing heterogeneity in choice analysis. Accounting for heterogeneity is important for understanding the distributional implications of management and policy decisions.

The latent class model (LCM) allows for incorporating individual characteristic data, both socio-economic and/or attitudinal data, to profile preference classes. Respondents can be categorized into a small number of classes, with class members having similar preferences while preferences can vary between the classes. The LCM introduces preference heterogeneity across individuals by assuming a discrete distribution of parameters. The individuals are then assigned probabilities to belong to given classes of a set of $C$ classes/groups that remain latent to the researcher. Within each class/group, the preferences are homogeneous (Greene, 2012). The idea is that, depending on individual tastes $\beta$, they can be 'segmented' into these classes. By using this model, one can estimate not only the share of the population in each class/group, but also the specific taste in each class/group (see Train, 2003, for a full description of the model). By doing so, the LCM adds to the understanding of the distribution of the effects of different forest landscape policy attributes among members of the sample.

The latent class model is specified as a random utility model where individual $i$ 's utility function associated with the preferred choice of policy program $p$ at choice situation $t$, given that he or she resides in class $c$ is:

$$
U_{i p t \mid c}=\alpha_{c p}+\boldsymbol{\beta}_{c}{ }^{\prime} \boldsymbol{x}_{i p t}+\varepsilon_{c i p t}
$$


The $\alpha_{c p}$ is the alternative-specific constants (ASC) for the status quo alternative. It captures the mean effect of unobserved utility for this alternative. Vector $\boldsymbol{x}$ describes the attributes, $\boldsymbol{\beta}$ is a vector of parameters and $\varepsilon_{\text {cipt }}$ is the unobserved component of utility, specified to be independently and identically distributed (IID) extreme value type 1. Following Greene \& Hensher (2003), the probability of individual $i$ choosing alternative $p$ is conditioned on belonging to class $c$ :

$$
P\left(y_{i t}=p \mid c\right)=\frac{\exp \left(\boldsymbol{\beta}_{c^{\prime}} \boldsymbol{x}_{i p t}\right)}{\sum_{p=1}^{P} \exp \left(\boldsymbol{\beta}_{c^{\prime}} \boldsymbol{x}_{i p t}\right)}
$$

The class membership for each individual is not observed by the analyst but can be informed by a vector of observable characteristics of the individual, $z_{i}$. Letting $H_{i c}$ represent the prior probability that individual $i$ belongs to class $c$ and $\theta_{c}$ are parameters that indicate the impact $z i$ have on class membership, then:

$$
H_{i c}=\frac{\exp \left(z_{i} \theta_{c}\right)}{\sum_{c=1}^{C} \exp \left(z_{i} \theta_{c}\right)} \quad \text { for } c=1, \ldots, \mathrm{C} \quad \theta_{C}=0
$$

To be able to identify the model, the parameter vector for class $C$ has to be set to zero. The probability that individual $i$ chooses policy $\operatorname{program} p$ is:

$$
P_{p}=\sum_{c=1}^{C} H_{i c} P_{p \mid c}
$$

Maximum likelihood is used to identify the values of the parameters that maximize the loglikelihood:

$$
\ln L=\sum_{i=1}^{N} \ln P_{i}=\sum_{i}^{N} \ln \left[\sum_{c=1}^{C} H_{i c}\left(\prod_{s=1}^{S_{i}} P_{i s \mid c}\right)\right]
$$




\subsection{Calculation of marginal willingness-to-pay}

When applying logit models, it is not meaningful to compare the size of the estimated coefficients among different model specifications. Fortunately, by transforming the results into marginal willingness-to-pay (WTP) measures, it is possible to analyse the relative importance of the attributes in question. Because the rate of trade-off between any two attributes is the ratio of their respective coefficients, the marginal WTP of each attribute is computed as the negative of the coefficient of that attribute, divided by the coefficient of the cost attribute. Thus, the marginal WTP for an arbitrary attribute $a$ is computed as:

$$
W T P_{a}=-\frac{\widehat{\beta}_{a}}{\widehat{\beta}_{\operatorname{cost}}}
$$

where $\hat{\beta}_{a}$ is the estimated coefficient for attribute $a$, and $\hat{\beta}_{\text {Cost }}$ is the estimated coefficient for the cost attribute.

Since the cost attribute is presented to the respondent in terms of percent of the present value of timber production, $W T P$ a will also be in percentage terms. To convert this to an estimate in Swedish kronor an estimate of the present value of timber production for the respondents is needed. To accomplish this we used 'Plan33', which is a Visual Basic computer program for economic forest management (cf. Ekvall, 2014, for a detailed description of Plan33). This program can be used to estimate the present value of timber production of an entire forest estate. To predict the present value of timber production from data available in the survey responses, 263 fictitious properties were simulated with the help of Plan33 and data from the Swedish National Forest Inventory. These estates were created to be a representative of the composition of Swedish privately owned forests. Each property consists of between 5 and 50 stands of varying age and composition from all four Swedish regions; Norra Norrland, Södra Norrland, Svealand and Götaland. It is assumed that the stands are managed according to normal Swedish forest practice, which can be defined as even-aged timber management including regeneration measures, intermediate cuttings and a final clearcut. Real estate prices and production costs are from 2017, and are the same as in Zabel et al. (2018). Each property was valued using Plan33, i.e. the present value of timber production was estimated for each one of the artificial estates using a 3 percent interest rate. These present values were then used as dependent variable in an 
ordinary least squares regression function, with average site quality class for the estate, average timber volume and a dummy variable each for region Norra Norrland, Södra Norrland and Svealand as independent variables. This regression function had an adjusted coefficient of determination of .96 , and all independent variables were significant at the 99.9 percent level (see Appendix). This regression equation was then used to predict the present value of timber production for all respondents in the sample who had answered the questions about average site quality class and timber volume for their estate. These values were later used to convert marginal WTP values from percentages to monetary units.

\subsection{Data collection}

A small pre-test, which was conducted on a group of 64 university students in the master of forestry programme at the Swedish University of Agricultural Sciences focused on the clarity of the questionnaire and the choice task before it was sent out to the respondents. The students at the master of forestry programme were chosen since they have an above average knowledge and interest in forest related issues. Their responses resulted in small adjustments in the formulation of the questions and the text in the questionnaire.

The final questionnaire consisted of three parts. The first part consisted of nine questions and concerned basic facts about the respondents' forest estate and general attitudes to nature conservation in the forest. Respondents were for instance asked if they consider nature conservation measures important to them as forest owners, if the creation of large continuous protected areas in the forest landscape important, and if they consider it important that they can influence the choice of protected areas in their forest.

The second part included the choice experiment exercise. Respondents were provided with information about the different attributes, and were then presented with the eight choice sets. For an example of a choice set, see Figure 1. This was followed by debriefing questions about whether they chose the status quo alternative for every choice set, and if so why, and if they disregarded any of the attributes in the choice sets. 
In the following you will be presented with alternative scenarios eight times. By comparing the values of the properties of the three alternatives, we want you to choose the alternative you prefer. At each repetition, the values of the properties will be a little different.

Choice set 1

\begin{tabular}{|l|l|l|l|}
\hline & Alternative A & Alternative B & Status quo \\
\hline $\begin{array}{l}\text { Selection of areas } \\
\text { for set-asides from } \\
\text { forestry? }\end{array}$ & $\begin{array}{l}\text { The forest owner } \\
\text { decides himself in } \\
\text { accordance with } \\
\text { current legislation. }\end{array}$ & $\begin{array}{l}\text { Society and the } \\
\text { forest owner decide } \\
\text { together, and the set- } \\
\text { asides are } \\
\text { distributed between } \\
\text { forest owners in } \\
\text { proportion to the } \\
\text { biological value of } \\
\text { the estate. }\end{array}$ & $\begin{array}{l}\text { The forest owner } \\
\text { decides himself in } \\
\text { accordance with } \\
\text { current legislation. }\end{array}$ \\
\hline $\begin{array}{l}\text { Tax base for a fee- } \\
\text { fund system? }\end{array}$ & $\begin{array}{l}\text { In proportion to the } \\
\text { production capacity } \\
\text { of the forest land. }\end{array}$ & $\begin{array}{l}\text { In proportion to the } \\
\text { size of the standing } \\
\text { timber volume. }\end{array}$ & $\begin{array}{l}\text { In proportion to } \\
\text { declared annual } \\
\text { income from the } \\
\text { forest estate. }\end{array}$ \\
\hline $\begin{array}{l}\text { Biannual nature } \\
\text { inventories? }\end{array}$ & Yes & Yes & No \\
\hline $\begin{array}{l}\text { Limit before } \\
\text { compensation is } \\
\text { paid }\end{array}$ & $15 \%$ & $5 \%$ & $5 \%$ \\
\hline My choice & & & \\
\hline
\end{tabular}

Figure 1. Example of a choice set

The third part of the questionnaire collected more detailed information about the respondents' forest estates, like tree species composition, timber volume, average site quality class, whether the estate is certified according to PEFC and FSC, and average cut volume and timber sales over the latest five year. The questionnaire ended with questions about the respondents' socioeconomic and demographic characteristics.

The final survey was implemented in November 2017 as a web survey, and a reminder was sent some weeks later. The survey could be filled out both on a computer and on a smartphone, and was distributed to two separate samples of Swedish forest owners. The first sample consisted of 2000 postal addresses randomly drawn from the Swedish Forest Agency's official registry of the almost 300000 NIPF owners in Sweden (henceforth the non-Prosilva sample). These addresses were drawn from all Swedish counties, except Gävleborg, Västernorrland, Jämtland, Västerbotten and Norrbotten, i.e. the counties jointly referred to as Norrland, the northernmost 
of the three traditional "lands" of Sweden. The second sample consisted of 1200 email addresses randomly drawn from the 2685 members of Forest certification Prosilva AB (henceforth the Prosilva sample), which is an umbrella organization for group certification of forest owners and forest entrepreneurs in accordance with both the Swedish PEFC and FSC standards. Prosilva's area of activity is mainly in Norrland, but also in the mid-Sweden counties of Värmland, Örebro, Dalarna, Västmanland and Uppland. Thus, by excluding Norrland from the first sample the risk of the same forest owner being included in both samples was minimized.

One of the 3 blocks of 8 choice sets was presented to the 1200 Prosilva respondents, while the two other blocks were presented to 1000 non-Prosilva respondents each. While this sampling strategy was borne out of necessity - Prosilva was approached after delays in the contacts with the Swedish Forest Agency - it provides an opportunity for a natural experiment. Since Prosilva membership is sought by the forest owners who are interested in certifying their forest according to the PEFC or FSC standards, there is reason to believe that Prosilva affiliated forest owners have an interest in nature conservation issues above the average forest owner. A Prosilva membership dummy was interacted with the ASC to investigate whether Prosilva affiliated forest owners were more likely to choose the status quo alternative. We tested for differences between the Prosilva and non-Prosilva groups on descriptive and attitude variables, and for most variables the differences were small. However, Prosilva forest owners derive a significantly higher percentage of their income from their forest (10.5\% vs. $6.3 \%)$, they are significantly more likely to have more than one forest property, they are significantly more likely to have woodland key biotopes on their property, and they are significantly more likely to let someone else manage their forest estate.

There is however here a small risk of confounding effects when interpreting the Prosilva dummy, since the non-Prosilva sample does not contain any forest owners from Norrland. Hence, if forest owners from Norrland have different preferences than forest owners in the rest of Sweden such a "Norrland effect" cannot be distinguished from a "Prosilva effect".

In the first sample 222 responses were received, while in the second sample 359 respondents answered the survey, both after one reminder, corresponding to a response rate of $11.1 \%$ and $29.9 \%$, respectively. The lower response rate for the non-Prosilva sample is due to several reasons, one being the different survey modalities for the two samples. The Prosilva sample was contacted through a mass email mailing, with the link to the web survey in the email. Since only postal addresses were available from the Swedish Forest Agency for the non-Prosilva sample they were contacted through a postcard which contained the link to the web survey. 
Arguably, it is easier to just click on a link in an email than to type in a web address printed on a post card. To reduce this burden QR codes were also provided on the postcard, which also linked directly to the web survey. Another possible reason for the difference in response rates is the fact that apparently the Swedish Forest Agency's registry was somewhat out-of-date. Many respondents from the non-Prosilva sample contacted the researchers, claiming that they had sold their forest estates several years ago. The extent of this over-coverage due to a flawed sampling frame is not known. A final reason for the higher response rate in the Prosilva sample is that they are likely to have an interest in nature conservation issues above the average forest owner.

\section{Results}

\subsection{Descriptive statistics}

Descriptive statistics on the survey respondents' demographic background, their forest property characteristics, and selected aspects of their forest management are presented in Table 2. To check for representativeness, we compare selected variables from each of these three sections to data from the 2014 Swedish Statistical Yearbook of Forestry (Skogsstyrelsen, 2014).

In the present sample almost $80 \%$ of respondents were men. Compared to the overall gender distribution of Swedish forest owners with $38 \%$ women and $61 \%$ men, women are underrepresented in our sample. Information on age is presented in age classes in the national statistics. Based on the age class data, the computed national mean age is 57.5 years, which is significantly ( $1 \%$ level) younger than the mean age of 61.5 years in our sample. Within the sample, the mean share of forest that is mature for final felling is $19.5 \%$. This is significantly less ( $1 \%$ level) than the national mean of $24 \%$ across all forest owner categories.

The total timber volume in Sweden in productive woodland is divided into about $39 \%$ pine, $42 \%$ spruce and $12 \%$ birch (Skogsstyrelsen, 2014). In our sample the share of deciduous forest is slightly lower, $10.94 \%$. The average standing volume per hectare of productive forest land is 135 m3sk per hectare in Sweden in general (Skogsstyrelsen, 2014) whereas for our sample the figure is $135.04 \mathrm{~m} 3 \mathrm{sk}$ per hectare, i.e. our sample mean almost perfectly coincides with the national average. For the forest estate area the sample mean is significantly higher than the national average for non-industrial forest owners of 48 hectares. However, we suspected that the sample mean is affected by misreporting from some respondents who have stated very high area figures. The figure corresponds fairly well with the sample in the survey of NIPF owners 
reported in Andersson (2010). It is reasonable to assume that forest owners with small holdings have a lower incentive to answers survey like these, with a correspondingly increasing effect on forest area sample means. 
Table 2: Descriptive statistics of survey data

\begin{tabular}{|c|c|c|c|c|c|c|c|}
\hline Variable & Mean & $\begin{array}{l}\text { Std. } \\
\text { dev. }\end{array}$ & Min. & Max. & Freq. & Percent & $\mathrm{N}$ \\
\hline \multicolumn{8}{|l|}{ Demographic background } \\
\hline Gender (male) & & & & & 362 & 79.56 & 455 \\
\hline Age (years) & 61.51 & 11.44 & 26 & 97 & & & 445 \\
\hline Persons in household & 2.25 & 0.98 & 0 & 6 & & & 446 \\
\hline Share of income from forest (\%) & 8.87 & 14.60 & 0 & 80 & & & 410 \\
\hline \multicolumn{8}{|l|}{ Forest property characteristics } \\
\hline No. of forest properties & 1.73 & 1.58 & 1 & 15 & & & 487 \\
\hline Area (hectares) ${ }^{* *}$ & 159.77 & 442.57 & 0 & 5000 & & & 480 \\
\hline Share coniferous forest (\%) & 70.71 & 21.32 & 0 & 100 & & & 414 \\
\hline Share deciduous forest (\%) & 10.94 & 13.10 & 0 & 100 & & & 349 \\
\hline Share mixed forest (\%) & 15.66 & 18.79 & 0 & 100 & & & 344 \\
\hline Share non-productive forest (\%) & 12.06 & 16.01 & 0 & 100 & & & 375 \\
\hline Average cubic meters per ha** & 135.04 & 71.02 & 0 & 600 & & & 327 \\
\hline Average site quality class** & 5.75 & 1.98 & 0 & 11.9 & & & 303 \\
\hline Share ready for clear-cut (\%) & 19.53 & 16.56 & 0 & 100 & & & 398 \\
\hline Ownership & & & & & & & 488 \\
\hline Private person(s) & & & & & 464 & 95.08 & \\
\hline Joint-stock company & & & & & 5 & 1.02 & \\
\hline Other $^{*}$ & & & & & 19 & 3.88 & \\
\hline
\end{tabular}

\section{Forest management}

\begin{tabular}{lccccccc}
\hline $\begin{array}{l}\text { Average income from timber } \\
\text { sales per year (SEK/year) }\end{array}$ & 171059 & 501799 & 0 & 5000 & & & 372 \\
Average cut volume (m $\left.\mathrm{m}^{3} / \mathrm{year}\right)$ & 524.92 & 1617.25 & 0 & 20000 & & & 332 \\
Certified through FSC or PEFC & & & & & 347 & 77.11 & 450 \\
Key biotope on property & & & & & 150 & 32.97 & 455 \\
Prosilva member & & & & & 303 & 61.96 & 489 \\
\hline
\end{tabular}

*Includes private foundations, cooperatives, general partnerships and estates of deceased persons. ${ }^{* *}$ Outliers that were outside the highest reported values in Sweden for these variables were excluded from the dataset. 
Furthermore, we collected data on the forest owners' education and professions. Of the sample, $33 \%$ have more than 3 years of post-high school education, 30\% have elementary education, $26 \%$ have high school education, $21 \%$ have less than 3 years of post-high school education, $12 \%$ have vocational training, $2 \%$ have a postgraduate education and $5 \%$ indicated that they have other types of education. In terms of profession, $37 \%$ of the survey respondents are retired, $29 \%$ are full-time employees, $13 \%$ are entrepreneurs, $6 \%$ are farmers, 5\% are part-time employees, $4 \%$ are forest owners by main occupation, $1 \%$ or less are in each of the categories early retirement, sick leave, and student, while $5 \%$ indicated that their occupation belongs to a category not mentioned here.

To investigate if there is any bias due to sampling only Prosilva members in Norrland, we tested for differences in socio-demographic background variables between Prosilva and non-Prosilva members. There is no significant difference (at $5 \%$ level) between the groups in terms of average age, size of estate, average cubic meter per hectare or average site quality class. However, Prosilva members, on average, derive a significantly larger share of income from their forest $(10.5 \%)$ than non-Prosilva members $(6.3 \%)$.

Three questions in the survey addressed respondents' general attitudes toward conservation aspects relevant to this research. They were asked to indicate whether they agree to the following statements i) "In the management of my forest, measures for nature conservation are important to me. Examples of such measures are to keep deadwood, leave high stumps or to increase the share of deciduous trees." ii) "It is important to create protected areas in forests that are connected." iii) "It is important that I can influence the choice of the protected area's location within my forest estate". Results on the extent to which the respondents agree to these three questions are reported in Figure 2. It is remarkable that more than $90 \%$ of the respondents indicate that they want to have a say in the decision on where exactly forest is set aside. Moreover, there appears to be a wide-spread general understanding of the need for biodiversity promoting management measures and the need for connectivity of conservation areas.

Estate size and membership in a forest owner association are among the factors that have previously been associated to forest owners' attitudes toward nature conservation (Widman 2015). An attempt to explain the answers to our questions with demographic controls, respondents' forest property characteristics and their management traits could not confirm the associations discussed in the literature. Indeed none of the models tested had an overall significance. 


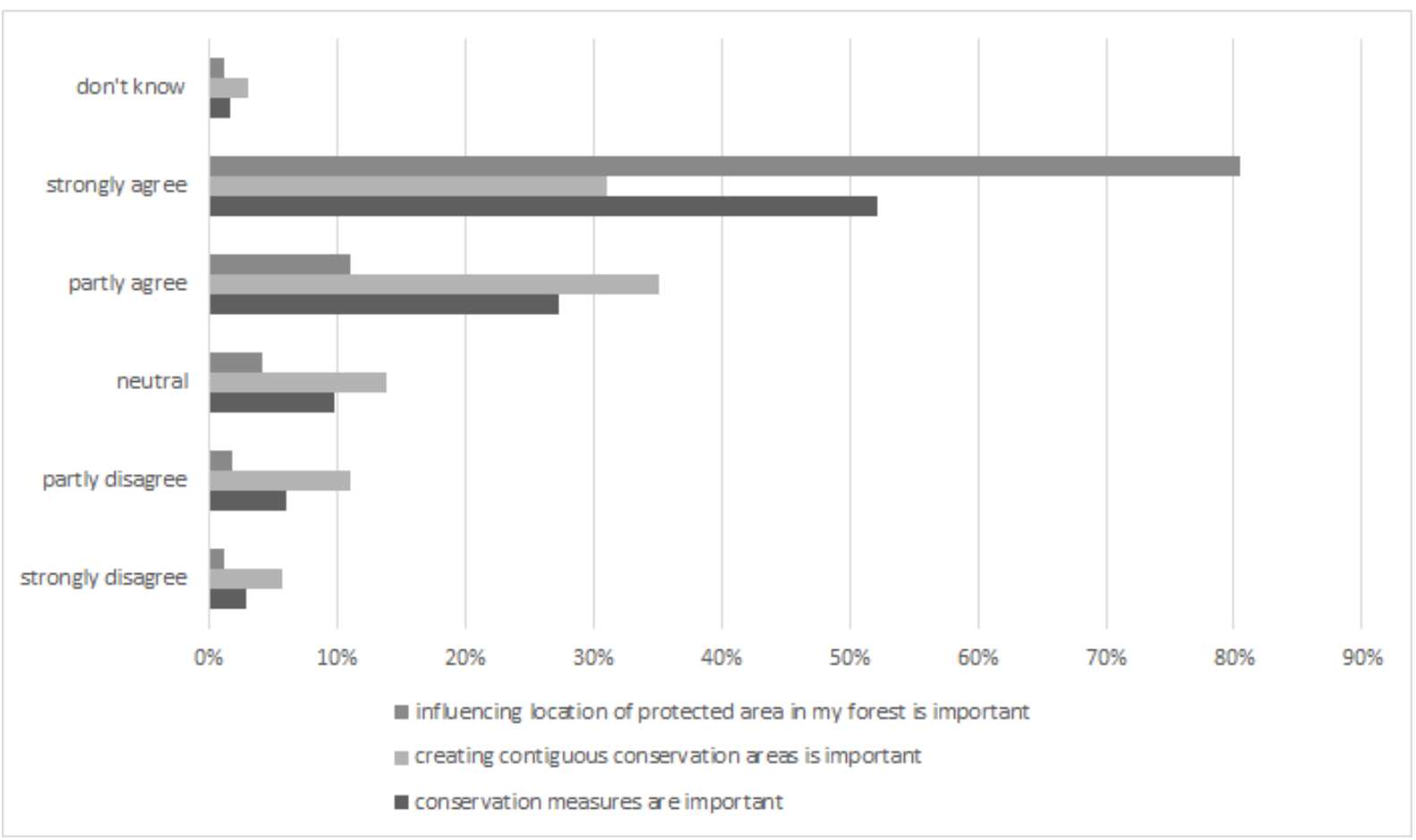

Figure 2: Respondents' attitudes towards selected aspects of conservation in forests.

\subsection{Choice model estimates}

The choice data were analyzed using NLOGIT 4.0 statistical software (Econometric Software, Inc., Plainview, NY). When support for new forest landscape policy is being sought, it can be helpful to segment the forest owners into different groups, to achieve a more detailed understanding of the preferences for different policy attributes in various groups. The LCM model provides an informative way of analyzing preference heterogeneity by being able to segment respondents into such groups. A LCM was therefore estimated to analyse and explain preference heterogeneity further. The LCM analyses preference heterogeneity by categorizing respondents according to a predetermined number of classes.

There is no theory for the right number of classes, but while more classes allow for a greater differentiation, too many classes may result in poor statistical fit of the model, difficulties in interpreting the results, or the estimated asymptotic covariance matrix will not be positive definite. According to Greene (2012), finding the appropriate number of latent classes for the LCM can be aided by different measures of model performance, such as Akaike information criterion (AIC) or the Bayesian information criterion (BIC) (see for example Beharry-Borg \& Scarpa, 2010 and Milon \& Scrogin, 2006). To establish the number of latent classes, BIC, AIC, the McFadden $R^{2}$, and the log-likelihood function values were used. Nonetheless, determining 
the number of latent classes is not merely a matter of choosing the model with the lowest BIC and/or AIC. These criteria only serve as a guide to determine the number of latent classes, and therefore judgement, by the analyst, regarding the appropriateness of the final number of classes should also guide the decision (Swait, 1994).

In the current study, the fit of the LCM was evaluated for between one and five classes, with the one class model being equivalent to a standard multinomial logit model (MNL). If one looks at the log-likelihood function value, the BIC, the AIC and the $R^{2}$ all improve when moving from one to two classes (see Table 3 below).

Table 3. Criteria for selecting the number of latent classes

\begin{tabular}{cllccc}
\hline No. of classes & $\begin{array}{l}\text { Log- } \\
\text { likelihood }\end{array}$ & BIC & AIC & $\begin{array}{l}\text { McFadden } \\
\mathbf{R}^{2}\end{array}$ & $\begin{array}{l}\text { Estimated } \\
\text { number of } \\
\text { parameters }\end{array}$ \\
\hline 1 & -3135.335 & 1.72256 & 1.70571 & .083 & 10 \\
\hline 2 & -2921.256 & 1.63096 & 1.59558 & .279 & 21 \\
\hline $\begin{array}{c}\text { (without soil } \\
\text { expectation term) }\end{array}$ & -2525.165 & 1.40866 & 1.37671 & .378 & 19 \\
\hline 3 & -2561.279 & 1.46024 & 1.40633 & .368 & 32 \\
\hline 3 & -2470.346 & 1.40122 & 1.35246 & .392 & 29 \\
\hline $\begin{array}{c}\text { (without soil } \\
\text { expectation term) }\end{array}$ & & & & & \\
\hline 4 & -2629.890 & 1.52194 & 1.44951 & .351 & 43 \\
\hline 5 & -2690.391 & 1.57925 & 1.48828 & .336 & 54 \\
\hline
\end{tabular}

Akaike Information Criterion $=-2(\operatorname{LogL}-\mathrm{P})$

Bayesian Information Criterion $=-\log L+(\mathrm{P} / 2) * \operatorname{Ln}(\mathrm{N})$

However, when using more than three classes the model performance estimators deteriorate, suggesting that the model with two or three classes provides the best fit. The two and three class models were also tested with and without an interaction term with the present value of timber production, and both performed better without this term. For this reason we have chosen to present in Table 4 below both the two and the three class models, but without this term. For completeness and comparison, MNL estimates are also presented. 
Table 4. Results from the multinomial logit (MNL) and latent class models (LCM), No. of obs.:3696

\begin{tabular}{|c|c|c|c|}
\hline Variable & MNL & LCM2 & LCM3 \\
\hline Society decides, bio & $-1.0354 * * *$ & $-2.5859 * * *$ & $-3.4406^{* * *}$ \\
\hline Society decides, area & $-1.1914 * * *$ & $-3.4245 * * *$ & $-3.5664 * * *$ \\
\hline Joint decision & $-.3180 * * *$ & $-1.3068^{* * *}$ & $-1.8330 * * *$ \\
\hline Tax soil & $.9823 * * *$ & $1.3967 * * *$ & $1.4825 * * *$ \\
\hline Tax timber & $.6723 * * *$ & $1.0325^{* * *}$ & $1.4698 * * *$ \\
\hline Nature inv. & $-.3610 * * *$ & $-.8352 * * *$ & $-.9766^{* * *}$ \\
\hline Cost & $-.0472 * * *$ & $-.0879 * * *$ & $-.0582 * * *$ \\
\hline Constant & $.6655^{* * *}$ & $1.3041 * * *$ & $1.7007 * * *$ \\
\hline Prosilva & .1058 & $-.4116^{* *}$ & $-.4816^{* *}$ \\
\hline Society decides, bio & & & $-1.2729 * * *$ \\
\hline Society decides, area & & & $-1.5087 * * *$ \\
\hline Joint decision & & & .5065 \\
\hline Tax soil & & & $2.1544 * * *$ \\
\hline Tax timber & & & $.6422 *$ \\
\hline Nature inv. & & & $-1.6038^{* * *}$ \\
\hline Cost & & & $-.2924 * * *$ \\
\hline Constant & & & $-.9982 * *$ \\
\hline Prosilva & & & -.3488 \\
\hline Society decides, bio & & -.0304 & -.0310 \\
\hline Society decides, area & & $-.2912 * * *$ & $-.2954 * *$ \\
\hline Joint decision & & $.6373 * * *$ & $.6325 * * *$ \\
\hline Tax soil & & $.8196^{* * *}$ & $.7482 * * *$ \\
\hline Tax timber & & $.6965 * * *$ & $.7156^{* * *}$ \\
\hline Nature inv. & & .04420 & $.1458^{*}$ \\
\hline Cost & & $-.0148 * *$ & .0049 \\
\hline Constant & & -.1845 & -.1477 \\
\hline Prosilva & & .0243 & .0262 \\
\hline Prob. Class 1 & & $.6930 * * *$ & $.6272 * * *$ \\
\hline Prob. Class 2 & & $.3070 * * *$ & $.1000 * * *$ \\
\hline Prob. Class 3 & & & $.2728 * * *$ \\
\hline McFadden Pseudo $\mathrm{R}^{2}$ & .083 & .378 & .392 \\
\hline
\end{tabular}


When moving from the multinomial logit through the two and three class latent class models a distinct pattern emerges. First, note how the parameter estimates for the three levels of the attribute "How are areas created as set-asides from forestry selected" are all negative, suggesting that all changes from the current state - that the forest owner decides himself - are perceived as a disutility in the multinomial logit model and in the first class of the latent class models. The absolute value of these parameter estimates increases for the first latent class when moving from two to three latent classes. For the second attribute, Which tax base should be used in a compensation system, it is the other way around - both levels, i.e. either taxing soil productivity or timber volume, are preferred to the current tax base, declared annual income from the forest estate, in the multinomial logit model and in the first class of the latent class models. Here also the absolute value of these parameter estimates increases for the first class when moving from two to three latent classes. The third attribute, Should decisions be based on biannual nature inventories, is also perceived as a disutility in the multinomial logit model and in the first class of the latent class models. Being a Prosilva member significantly reduces the preference for the status quo alternative in the first latent class.

The second class in the two class latent class model has been deliberately placed adjacent to the third class in the three class model for ease of comparison. By doing so it becomes obvious that the classes are very similar. In these classes the level "Society decides, bio" i.e. society decides, and the set-asides are distributed between forest owners in proportion to the biological value of the estate, is not significant, while the level "Joint decision", i.e. society and the forest owner decide together, and the set-asides are distributed between forest owners in proportion to the biological value of the estate, actually provide significant positive utility. This suggests that forest owners in these classes would prefer a joint decision with representatives of a government authority to deciding about set-asides themselves. The level "Society decides, area" still provides significant disutility in these classes. As with the first latent class, both levels, i.e. either taxing soil productivity or timber volume, are preferred to the current tax base. As for the third attribute, Should decisions be based on biannual nature inventories, it actually provides significant positive utility in the third class of the three class model. Prosilva membership has no effect on the preference for the status quo alternative in these classes.

The second class in the three class model has similar preferences to the models' first class, with the notable exception of the level "Joint decision", being insignificant, and the parameter estimates of the other two levels of the attribute "How are areas created as set-asides from forestry selected" being smaller in absolute value. 


\subsection{Interpretation of groups}

Based on this we can attempt the following typology of the respondents. The first group is about 63 to 69 percent of the respondents, and they are blatantly opposed to all reductions in their freedom to decide on the location of set-asides and to the notion of biannual nature inventories to determine biologically valuable sites for set-asides. They are however positive to changing the tax base used to calculate the limit for when land use is significantly hampered and compensation should be paid from the current base, declared annual income from the forest estate, to either taxing soil productivity or timber volume.

The second group is about 27 to 30 percent of the respondents. They would not get a significant disutility form societal decision making of set-asides, if the decision is based on biological value of the set-asides. They even get a positive utility of joint decision making of set-asides, and biannual nature inventories. They are also positive to changing the tax base in the same way as the first class.

In the three class model the picture becomes somewhat more nuanced, since it is mainly the first class that reduces in size to form an intermediate group, which is about 10 percent of the respondents. This group is less negative to reductions in their freedom to decide on the location of set-asides, and would not get a significant disutility from joint decision making of set-asides. In the latent class models posterior probabilities for belonging to a certain class for each respondent can be retained in the estimation. Classifying these posterior probabilities as one if the probability of belonging to class 1 is above .5, and zero otherwise, 69.7 percent of the respondents belonged to class 1 . This binary variable was then used in logit or probit estimations to determine if socioeconomic variables can explain the latent class classification. The forecasted present value of timber production, Prosilva membership, respondent gender, education level and age, and whether the forest estate was FSC or PEFC certified was used as explanatory variables. Contrary to expectation, only Prosilva membership and FSC or PEFC certification significantly determined the posterior likelihood of belonging to class 1 . None of the respondent demographic variables were significant. Thus, while latent class 1 members apparently are spread over all ages, education levels and both genders, Prosilva members are more likely to be opposed to reductions in their freedom to decide on the location of set-asides and to the notion of biannual nature inventories. Then again, as referred to in the method section, this might be due to a "Norrland effect" rather than a "Prosilva effect". 


\subsection{Lexicographic preferences}

We also asked the subset of 99 respondents (20\% of the sample) who persistently chose the status quo option across all eight choice sets to explain their motivation for doing so. In descending order of frequency the respondents provided these explanations: the current system shouldn't be changed (47\%), landscape planning is only acceptable if full compensation is offered $(29 \%)$, the different scenarios were too difficult $(24 \%)$, more information on the ecological effects of landscape planning is necessary (20\%), more information on the economic effects of landscape planning is necessary (20\%), explanations were not sufficiently detailed to make a decision (13\%), nature conservation is not important $(2 \%) .11 \%$ indicated that other reasons than the given answer options had influenced their decision $(11 \%)$.

\subsection{Marginal willingness-to-pay}

The above mentioned posterior probabilities of belonging to a certain class for each respondent can also be used to calculate individual marginal WTP values. First, as described in the Method section, the marginal WTP of each attribute is computed as the negative of the coefficient of that attribute, divided by the coefficient of the cost attribute. This is done for each class separately. Since the cost attribute was not significant for all classes in the three class LCM, the two class model was used. This gives the marginal WTP of a certain attribute level in percentage terms, given that a certain respondent belongs to this class. For each individual, a weighted average is then calculated using the posterior probabilities of belonging to a certain class for this respondent. This individual marginal WTP in percentage terms is then converted to decimal form and multiplied with the forecasted present value of timber production for that respondent's forest estate, which gives an individual marginal WTP in SEK. Since the attributes "Society decides, bio" and "Nature inv.", and hence, their marginal WTP in percentage terms, were insignificant in class 2 the value zero was used there.

Table 5 displays the mean and $95 \%$ confidence interval for the individual marginal WTP in SEK and in percent of the present value of timber production. Note that a negative value means that the mean marginal WTP for that attribute level is negative, i.e. there is a positive marginal WTP to avoid such a change in forest policy as that attribute level implies. Conversely, in the case of a positive mean marginal WTP the respondents are willing to accept more set-asides before compensation is paid following such a change in forest policy. 
Table 5. Marginal WTP in SEK. $95 \%$ confidence intervals are in brackets.

\begin{tabular}{|c|c|c|}
\hline Attribute & $\begin{array}{l}\text { Marginal WTP } \\
\text { (SEK) }\end{array}$ & $\begin{array}{c}\text { Marginal WTP } \\
\text { (percent of soil expectation } \\
\text { value) }\end{array}$ \\
\hline Socbio. & 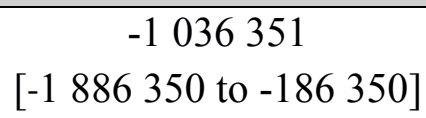 & $\begin{array}{c}-20,38 \\
{[-21.2 \text { to }-18.8]}\end{array}$ \\
\hline Socarea & $\begin{array}{c}-1519472 \\
{[-2719472 \text { to }-319472]}\end{array}$ & $\begin{array}{c}-33,02 \\
{[-33.73 \text { to }-32.27]}\end{array}$ \\
\hline Together & 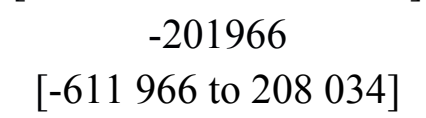 & $\begin{array}{c}2,88 \\
{[-0.29 \text { to } 4.3]}\end{array}$ \\
\hline Taxsoil & $\begin{array}{c}973560 \\
{[423560 \text { to } 1523560]}\end{array}$ & $\begin{array}{c}27,96 \\
{[25.4 \text { to } 28.6]}\end{array}$ \\
\hline Taxtimb. & $\begin{array}{c}765443 \\
{[345442 \text { to } 1185442}\end{array}$ & $\begin{array}{c}22,54 \\
{[20.6 \text { to } 23.4]}\end{array}$ \\
\hline Nature inv. & $\begin{array}{c}-334731 \\
{[-614731 \text { to }-54731]}\end{array}$ & $\begin{array}{c}-6,58 \\
{[-6.36 \text { to }-5.64]}\end{array}$ \\
\hline
\end{tabular}

$1 \mathrm{SEK} \approx .09$ EUR (April 2018)

Notable are the significant and large negative marginal WTP estimates for the attributes "Socbio" and "Socarea". This indicates that the forest owner respondents would, in principle, be willing to pay significant sums in terms of larger set-asides before compensation is paid to avoid entirely losing the right to determine where in their estate set-asides should be located. However, the marginal WTP for the attribute "Together" is not significantly separate from zero, suggesting that joint decisionmaking on the location of set-asides is not worse than the status quo.

The marginal WTP for the attributes "Taxsoil" and "Taxtimb" are both significantly positive, suggesting that a possible future tax-fund system should not be based on the declared annual income from the forest estate, the current base for income taxation, but on either the production capacity of the forest land or the standing timber volume of the forest estate. Finally, the marginal WTP for the attribute "Nature inv" is significantly negative, but relatively small in value, suggesting that biannual nature inventories is regarded as a disutility for the average respondent. 


\section{Policy implications}

Landscape planning for conservation is often discussed as a promising and cost-effective approach to reconcile competing land uses with conservation (Sayer et al. 2013, Kennedy et al. 2016). However, policy design becomes difficult when environmentally valuable areas are unequally distributed among landowners, and when land owners are very negative towards any policy change that involves entirely losing the right to determine where in their estate set-asides should be located. At the same time the unequal distribution of ecologically valuable sites between forest owners means that a continuation of the present Swedish forest conservation policy will result in economic inefficiencies and a fragmented conservation landscape.

The tax-fund system proposed in Zabel et al. (2018) seeks to support a forest landscape policy by levelling out differences in the financial burden for conservation by imposing a tax or fee on non-conserved land, where the funds generated are used to compensate for the opportunity cost of the conserved land. A recommendation based on the results of the choice experiment would be to consider alimenting such a fund using a site quality tax or a tax in proportion to the size of the standing timber volume. However, while forest owners appear to prefer both over the current use of the declared annual income from the forest estate, it is important to keep in mind that the choice of tax base can have effects on rotation length which in turn have effects on biodiversity (Roberge et al. 2018). If the forest owner follows a Faustmann-type production system, the current income tax creates incentives to lengthen rotation age, which on the one hand is a distortion of marginal harvest decisions, but on the other hand may be a positive effect from an ecological perspective. Older forests for example provide more dead wood for saproxylic species, often have less edges and provide a longer time span for population growth of specialist species (Ranius et al. 2003, Dettki \& Esseen 2003, Thompson 1993). By contrast, a site quality tax would have no effect on rotation age. A timber tax would decrease rotation age (Amacher et al. 2009), which again is a distortion of marginal harvest decisions, but could benefit species requiring sun exposed dead wood and open habitats while additionally decreasing risks of climate change hazards and allowing for more dynamic management patterns (Schöttker et al. 2016, Roberge et al. 2018).

Nonetheless, from the results above it is obvious that addressing horizontal equity in this way is not sufficient to obtain acceptance from the forest owners' community for such a policy. Currently, Swedish forest policy builds on a "freedom with responsibility principle" which grants forest owners wide-ranging discretion in the management of their forests (Lindahl et al. 2017). The results of the choice experiment revealed that most forest owners seem to have a 
strong intrinsic valuation of the right to determine where set-asides should be located and will be very negative towards any infraction of these rights. These forest owners will see any kind of restriction as a potential cost. However, the results also reveal some avenues for future proactive forest policies, since joint decisionmaking on the location of set-asides seems acceptable to many forest owners. Some voluntary policies that allow for concerted decision making between landowners and administrations and support contiguous set asides already exist in other contexts. For example, in agglomeration bonus payments landowners decide on their set aside location and receive a bonus payment, if the chosen location is adjacent to that of a neighbour (Parkhurst \& Shogren 2007). Such a bonus payment could perhaps be refined to take into account the ecological quality of a site. An alternative approach is exemplified by socalled "land stewardship" programs, where groups of neighbouring landowners compete for funding to voluntarily implement coordinated conservation actions (Prager \& Vanclay 2010). In the Swedish context this could imply that forest owners may jointly submit a proposal for financial compensation for set-asides that are connected across their estates.

Such policies would mark a departure from the current reactive decision making policy by the Swedish Forest Agency and the county administrative boards. Today (2018), the Forest Agency allows the destruction of breeding sites and other types of habitat in case by case assessments of felling notifications, until the number of remaining breeding sites/habitats are so few that the ecological functionality in the region is threatened. The Section 4 of Swedish Species Regulations is activated and the Forest Agency are obliged to halt the next felling that is notified by a NIPF owner. This "first come, first served" approach - due to the fragmentation counteracts a strategic conservation approach and a prioritizing of the most valuable conservation objects (Michanek et al. 2018). The problems with this reactive approach have also been highlighted by the Swedish National Audit Office (Riksrevisionen) in a review of the cost-efficiency of Swedish forest conservation measures (Riksrevisionen, 2018). They note that "authorities should work preventively to prevent clear-cuts and other measures that significantly impair natural values in areas that have such preservation values that they should be a priority for formal protection. In order to be able to work systematically with the strategy's priorities, it is important to minimize the number of cases initiated by felling reports."

Although there seem to be considerable opportunities for improvements in decision making that would also be potentially acceptable to the forest owners - any proactive approach must be based on comprehensive and updated nature inventories. This could pose a problem, since the survey results reveal strong negative marginal WTP for biannual nature inventories. The 
negative attitudes from the forest owners towards nature inventories are likely to be driven by anxiety for what biological values such an inventory might uncover on their estate. However it is important to keep in mind that the survey was conducted at a time when key-biotope inventories were high on the political agenda. If a tax-fund system were to be implemented, the Forest Agency would need to devote considerable efforts to explain that increased demands for conservation for an individual forest owner would not mean an increased financial burden.

\section{Discussion}

In Sweden, national forest conservation goals are off target, largely due to a reactive and nonstrategic conservation approach that has not been able to halt the decrease of old-growth forests and increase in forest fragmentation. There is dire need for new policies that coordinate conservation at a landscape scale and deal with the unequal distribution of remaining ecologically valuable forests across forest owners. A tax-fund system, building on the concept of common but differentiated responsibility, has been proposed as novel policy option for these heterogeneous forest landscapes (Zabel et al. 2018). However, given that about 50 percent of the Swedish forests is owned by some 300000 NIPF owners it is crucial that such a system takes the preferences of these forest owners into account. In this paper, we present results of a stated choice experiment that provide insights on forest owners' preferences on key attributes relevant to such a tax-fund system. Two distinct groups stand out in the choice experiment data: members of the first are blatantly opposed to interventions that could curtail their liberty in deciding on the location of set-asides and oppose frequent nature inventories on their estates. The second, smaller group would indeed derive positive utility from jointly deciding on the location of set-asides with society. Both groups would prefer changing the current tax-base to soil productivity or timber volume.

For practical reasons, two forest owner samples were combined for this analysis. The response rates of $11.1 \%$ and $29.9 \%$, respectively are moderate for a choice experiment. Although both are random samples, average values on several socio-economic background variables in our combined dataset were significantly different from corresponding official nation-wide averages. This suggests that inferences should me made with care.

In the previous section we discussed specific policy recommendations building on the results of the choice experiment. Yet, throughout this research it became apparent that the conservation debate in the Swedish forest sector is highly polarized, leaving little scope for the discussion of 
new ideas and concepts among various forest stakeholders. To avoid political stalemate to the detriment of forest conservation, round tables or think tanks with representatives of all relevant stakeholder groups are needed to move forward. Forums like these could contribute to a factual discussion and development of new ideas outside of stakeholders' policy agendas.

\section{Acknowledgements}

We kindly acknowledge funding by the Swedish Environmental Protection Agency Dnr: 8020243-15. Additionally, Göran Bostedt acknowledges funding from EFINORD, the Northern Regional Office of the European Forest Institute. We appreciate comments by Sandra Schusser, Jens Abildtrup, Benjamin Ouvrard and Brian Danley. 


\section{Appendix*}

Regression function estimating present value, SEK/ha, of timber production for each forest property

\begin{tabular}{lcccc}
\hline Variable & $\begin{array}{c}\text { Parameter } \\
\text { value }\end{array}$ & $\begin{array}{c}\text { Standard } \\
\text { error }\end{array}$ & t-test & p-value \\
\hline Constant & -8509 & 1645 & -5.17 & $<0.00005$ \\
Average Volume, $\mathrm{m}^{3} / \mathrm{ha}$ & 127.2 & 3.850 & 33.03 & $<0.00005$ \\
Dummy Svealand & -5409 & 408.4 & -13.24 & $<0.00005$ \\
Dummy Södra Norrland & -5685 & 610.1 & -9.32 & $<0.00005$ \\
$\begin{array}{l}\text { Average site quality, } \mathrm{m}^{3} / \mathrm{ha} \& \\
\text { year }\end{array}$ & 2262 & 259.1 & 8.73 & $<0.00005$ \\
Dummy Norra Norrland & -4526 & 983.7 & -4.60 & $<0.00005$ \\
\hline
\end{tabular}

*Will be provided as online supplement when/if the paper is accepted. 


\section{References}

Amacher, G., Ollikainen, M., Koskela, E., 2009. Economics of Forest Resources. The MIT Press, Cambridge MA.

Andersson, M., 2010. Non-industrial Private Forest Owner's Management Decisions. PhD Thesis. Swedish University of Agricultural Sciences, Umeå.

Appelstrand, M. 2012. Developments in Swedish forest policy and administration - from a “policy of restriction" toward a "policy of cooperation". Scand. J. Forest Res. 27, 186199.

Beharry-Borg, N., Scarpa, R. 2010. Valuing quality changes in Caribbean coastal waters for heterogeneous beach visitors. Ecol. Econ. 69, 1124-1139.

Bush, T. 2010. Biodiversity and sectoral responsibility in the development of Swedish forestry policy, 1988-1993. Scand. J. Hist. 35, 471-498.

Cazorla, M., Toman, M. 2000. International equity and climate change policy. Climate Issue Brief No. 27, Resources For the Future, Washington DC.

Dettki, H., Essen, P-A. 2003. Modelling long-term effects of forest management on epiphytic lichens in Northern Sweden. Forest Ecol. Man. 175, 223-238.

Dreyer. S.J., Teisl, M.F., McCoy, S.K. 2015. Are acceptance, support, and the factors that affect them, different? Examining perceptions of U.S. fuel economy standards. Transport Res. D - Tr. E 39, 65-75.

Dreyer, S.J., Walker, I. 2013. Acceptance and support of the Australian carbon policy. Soc. Justice Res. 26(3), 343-362.

Ekvall, H. 2014. Cost-effectiveness of measures to improve biodiversity in Swedish forests. PhD thesis 2014.3, Faculty of Forest Sciences, Swedish University of Agricultural Sciences, Umeå.

Englin, J., Klan, M. 1990. Optimal taxation: timber and externalities. J. Environ. Econ. Man. $18,263-275$.

Forsberg, M. 2012. Skogen som livsmiljö - En rättsvetenskaplig studie om skyddet för biologisk mångfald. $\mathrm{PhD}$ thesis, Uppsala University.

Greene, W.H. 2012. Econometric analysis. Pearson, Boston. 
Kennedy, C.M., Miteva, D.A., Baumgarten, L., Hawthorne, P.L., Sochi, K., Polasky, S., Oakleaf, J.R., Uhlhorn, E.M., Kiesecker, J. 2016. Bigger is better: improved nature conservation and economic returns from landscape-level mitigation. Sci. Adv. 2, e1501021.

Kirschner, A.R. 2010. Understanding poverty and unemployment on the Olympic Peninsula after the spotted owl. Soc. Sci. J. 47, 344-358.

KSLA 2015. Forests and forestry in Sweden. The Royal Swedish Academy of Agriculture and Forestry (KSLA), Stockholm

Larsson, M. 2017. Ingen lugn paus. Skogseko 32(2), 14-17.

Liljenström, S., Kvarnbäck, M. (Eds.) 2008. Sweden's environmental objectives in brief: a summary of the Swedish Environmental Objectives Council's evaluation. Swedish Environmental Protection Agency, Stockholm.

Beland Lindahl, K., Sténs, A., Sandström, C., Johansson, J., Lidskog, R., Ranius, T., Roberge, J-M. 2017. The Swedish forestry model: More of everything? Forest Policy Econ. 77, 4455.

Löfmarck, E., Uggla, Y., Lidskog, R. 2017. Freedom with what? Interpretations of "responsibility" in Swedish forestry practice. Forest Policy Econ. 75, 34-40

McFadden, D. 1974. Conditional logit analysis of qualitative choice behavior. In: Zarembka, P. (Ed.) Frontiers in Econometrics. New York, NY, Academic Press.

Michanek, G., Bostedt, G., Ekvall, H., Forsberg, M., Hof, A.R., de Jong, J., Rudolphi, J., Zabel, A. 2018. Landscape planning - Paving the way for effective conservation of forest biodiversity and a diverse forestry? Forestry, 9, 523.

Milon, J.W., Scrogin, D. 2006. Latent preferences and valuation of wetland ecosystem restoration. Ecol. Econ. 56, 162-175.

Naturvårdsverket 2017. Miljömålen - Årlig uppföljning av Sveriges nationella miljömål 2017. Report 6749, Swedish Environmental Protection Agency, Stockholm.

Parkhurst, G.M., Shogren, J.F. 2007. Spatial incentives to coordinate contiguous habitat. Ecol. Econ. 64(2), 344-355.

Pešut, I. 2011. Croatia's fee for the use of public benefit functions of forests. Presentation 4-5 July 2011, United Nations, Geneva. 
(https://www.unece.org/fileadmin/DAM/timber/meetings/20110704/4-Ivana-pesutPES_Croatia.pdf).

Prager, K., Vanclay, F. 2010. Landcare in Australia and Germany: comparing structures and policies for community engagement in natural resource management. Ecol. Manag. Restor. 11, 187-193.

Ranius, T., Kindvall, O., Kruys, N., Jonsson, B.G. 2003. Modelling dead wood in Norway spruce stands subject to different management regimes. Forest Ecol. Man. 182, 13-29.

Riksrevisionen 2018. Skyddet av värdefull skog. RIR 2018:17, Swedish National Audit Office, Stockholm.

Roberge, J-M., Öhman, K., Lämås, T., Felton, A., Ranius, T., Lundmark, T., Nordin, A. 2018. Modified forest rotation lengths: Long-term effects on landscape-scale habitat availability for specialized species. J. Environ. Man. 210, 1-9.

Sayer, J., Sunderland, T., Ghazoul, J., Pfund, J-L., Sheil, D., Meijaard, E., Venter, M., Boedhihartono, A.K., Day, M., Garcia, C., van Oosten, C., Buck, L.E. 2013. Ten principles for a landscape approach to reconciling agriculture, conservation, and other competing land uses. P. Natl. Acad. Sci. USA 110(21), 8349-8356.

Ščasný, M., Zvěřinová, I., Czajkowski, M., Kyselá, E., Zagórska, K. 2017. Public acceptability of climate change mitigation policies: a discrete choice experiment. Clim. Policy 17, S111-S130.

Schöttker, O., Johst, K., Drechsler, M., Wätzold, F. 2016. Land for biodiversity conservation to buy or borrow? Ecol. Econ. 129, 94-103.

Skogsstyrelsen 2014. Swedish Statistical Yearbook of Forestry 2014. Swedish Forest Agency, Jönköping.

Street, D.J., Burgess, L.L. 2007. The Construction of Optimal Stated Choice Experiments: Theory and Methods. Wiley, New York.

Swait, J. 1994. A structural equation model of latent segmentation and product choice for crosssectional revealed preference choice data. J. Retailing Cons. Serv. 1, 77-89.

Thompson, F.R. 1993. Simulated responses of a forest-interior bird population to forest management options in Central hardwood forests of the United States. Cons. Biol. 7, 325333. 
Train, K. 2003. Discrete Choice Methods with Simulation. Cambridge University Press, Cambridge.

Zabel, A., Bostedt, G., Ekvall, H. 2018. Policies for forest landscape management - A conceptual approach with an empirical application for Swedish conditions. Forest Policy Econ. 86, 13-21.

Widman, U. 2015. Shared responsibility for forest protection? Forest Policy Econ. 50, 220-227. 